\title{
The Role of Chemical Agents in the Microbial Flora with Major Risk of Interventios in Maxilo-facial Surgery
}

\author{
CARMEN GABRIELA STELEA ${ }^{1}$, IULIAN CONSTANTIN²*, CRISTIAN BUDACU ${ }^{1 *}$, ALEXANDRA LORINA PLATON ${ }^{1}$, MIHAIL BALAN ${ }^{1 *}$, \\ LILIANA PAVEL ${ }^{2}$, IOAN SIRBU ${ }^{3}$, MIHAELA GABRIELA LUCA ${ }^{4}$, MIHAI CONSTANTIN ${ }^{1}$ \\ ${ }^{1}$ Grigore T. Popa University of Medicine and Pharmacy, Faculty of Dental Medicine, 16 Universitatii Str., 700115, Iasi, Romania \\ ${ }^{2}$ Dunarea de J os University of Galati, Faculty of Medicine and Pharmacy, 47 Domneasca Str., 800008, Galati, Romania \\ ${ }^{3}$ Carol Davila University of Medicine and Pharmacy, Faculty of Dental Medicine,17-23 Calea Plevnei, 010221, Bucharest, Romania \\ ${ }^{4}$ University of Medicine, Pharmacy, Sciences and Technology, 38 Gheorghe Marinescu Str., 540139, Targu Mures, Romania
}

\begin{abstract}
The pathology of the oro-maxilo-facial territory comprises a vast chapter of diseases with primary or secondary infectious etiology, the mouth being the natural cavity of the organism with the most varied and variable flora of bacterial contamination. By the continuity solutions created by the mechanical act of mastication, decubitus of defective prosthetic works, local dento-periodontal infectious processes, but especially of dental or small-scale interventions, open gates and possibilities of penetration into the blood circulation of the microorganisms, which cause the transient bacteria. The study included 243 randomly selected patients, with the address of the Oral and Maxillofacial Surgery Clinic in the period 2016-2018. The inoculation of microorganisms in the oral cavity in circulating blood as a result of oral surgery or dental care procedures is much more common than in other areas of the body. Aggressive dental maneuvers that create solutions of continuity of oral mucosa, gingiva, periodontal surgery, periodontal surgery techniques can cause bacteria.
\end{abstract}

Keywords: infectious etiology, microbial flora, maxillo-facial surgery, infectious complications, remodeling

Typically, the bacteremic condition is devoid of clinical expression or accompanies only to chills and fever, to which symptoms and signs may be added to the condition that caused microbial discharge.Debre defined bacteremia as the ephemeral passage, sometimes latent, often direct, sometimes noisy, of germs in the blood. Human blood is normally sterile because the circulatory system has the ability to eliminate microorganisms.Buiuc said that bacteremia is present in the blood of bacteria from a septic outbreak or from a damaged mucosa[1-3].

Although initially bacteremia was considered by some authors as a consequence of dental extractions, other publications that have been criminalizing the etiopathogenesis of bacteremia and other dental procedures have appeared in the literature. The oral cavity can contain most of the known bacteria. A very large number of bacteria are fed by the diet and breathing air, others are accidentally introduced after traumatic lesions of soft, jawed or dento-periodontal bones, over time what an important group is the permanent flora.The permanent flora of the oral cavity was named by Kritcherosky and Seguin as the fundamental flora of the oral cavity [4-6].

Numerous studies have been concerned with the research of the fundamental flora of the oral cavity, yet the oral ecosystem is of considerable complexity and has not yet been fully investigated and identified.The occurring microorganisms of the oral cavity with due fundamental flora usually remain in the state commensal, under the conditions of a normal biological balance of the body [ 79].

This commensal state is determined by a particularly active local defense provided by numerous phagocytes, the barrier against which the oral mucosa opposes and the bactericidal properties of saliva. The vital competition of various microbial species (the phenomenon of antagonism) also intervenes in maintaining the balance of the oral fundamental flora [10-12].
The floral of the oral cavity is of extreme wealth being superior even to the intestinal flora.

The nutritional and physicochemical conditions specific to certain areas of the skin and mucosa, select bacterial species that will colonize at these levels, forming as a whole an ecological entity called indigenous microbiota [13-15].

The anatomical oral mucosa with its numerous replicas together with the other retention areas are the specific elements of the oral cavity that explain the extreme and impressively varied and variable richness of the microbial flora of the oral cavity.

The microbial flora of the oral cavity includes two groups of microorganisms: resident (permanent) and floating (temporary):

Residual microorganisms are well-suited to the developmental conditions offered by different regions of the oral cavity and under normal health conditions are harmless to the body (e.g. Streptococci viridans, Lactobacilli) $[1,17,18]$.

Floating microorganisms are less well adapted and therefore have a low persistence time. From this group, under certain favorable conditions (e.g. lesions of oral mucosa, alteration of residual microbes by the use of oral broad-spectrum antibiotics, etc.), some pathogenconditioned species can penetrate into the tissues, leading to infections (e.g., Staphylococcus aureus, Actinomyces israelli, yeasts of the genus Candida, etc.).The microbial flora of the oral cavity is dominated by bacteria and fungi. To fix bacteria, the oral cavity offers two types of surfaces: the surface of the hard and reminiscent teeth; the surface of the soft shells and constantly renewed by desquamation of the mal pighian epithelium. As a result, the composition and density of the oral microbiota as well as the intraoral distribution of the bacterial species varies on different oral surfaces [19-21].

For example Streptococcus mutans and Streptococcus blood, Lactobacillus and some gram-positive

\footnotetext{
* email: drconstantiniulian@gmail.com; cristibudacu@yahoo.com, mihail.balan@umfiasi.ro
} 
bacteria of the genera Actinomyces, Bacterionema, Rothia are to a greater extent on the surface of the teeth, while Streptococcus salivarius to colonize preferentially the dorsal surface of the tongue.

Other species such as some Gram-negative bacteria of the genus Bacteroides, Fusobacterium, Leptotrichia and Veillonella predominate in the gingival sulcus and periodontal pouches where the oxygen concentration is lower [22-24].

However, the microbial flora of the oral biotope varies as composition and density from person to person and in relation to diet, saliva flow and $\mathrm{pH}$, oral hygiene, the presence or absence of the dental plaque.

Numerous studies have been conducted by some authors to make correlations between the oral cavity microorganisms and the clinical forms of oro-maxillofacial suppositories on the one hand and the correlation with remote localizations following the hematogenic dissemination of micro-organisms from oral infectious outbreaks [25- 29].

Although the theory that an infectious process has an evolution dependent on the anatomical particularities of the territory where it occurs, the virulence of microbial flora and its own dynamics of development of suppuration is widely accepted, there are still many unknowns.

The difficulty in explaining this relationship lies in the complexity of the infectious etiology, mostly polymicrobial, in which the most strictly anaerobic bacteria ( Peptostreptococcus, Actinomyces, Veillonella, Prevotella, Bacteroides, Compylobacter, Fusobacterium etc.) make up most of the oral residual flora. How ever, strictly anaerobic bacteria together with the microbial flora normally present in the oral and facultative anaerobic bacteria (Streptococcus oral, Lactobaccillus, Corynebacterium, etc.) and in the absence of oral hygiene and promiscuity occur even protozoars (Entamoeba gingivalis and Trichomonas tenax).

In the case of invasive explorations, surgery, dental care, oral mucosal lesions, etc., the saprophytic (nonpathogenic) microorganisms avoids the host's defense strategies becoming pathogenic.Oral bacterial microflora that isolates itself from the very first few hours of life of the newborn persists throughout its existence [30-32].

This ever-changing and diversifying microbial flora, depending on the natural sequence of the transition from the infant to the elderly, may still be in a favorable balance if the patients adhere to the rules of hygiene, oral mucosa, teeth, periodontium and the tonsils are healthy or if the maintenance treatments are done in a timely and properly qualitative manner [33-35].

Non-transient and non-clinical bacteria have been highlighted by positive hemocultures in surgical patients, whatever they may be, and whatever the aseptic precautions taken.

The percentage difference in positivity of hemocultures is attributed to the different working conditions and the amount of blood taken for hemocultures. The higher the amount of blood and the closest to the moment of surgery, the greater the chances of positive hemocultures.

Under normal circumstances, the body's defense power is capable of destroying invading germs. As evidence, 18 $h$ after the surgical procedure, hemocultures are negative.

It was found that among the usual postoperative reactions are the increased temperature and chills, the latter being considered as the expression of a bacterial invasion. But it cannot be confirmed with certainty that a bacteremia must always cause chills. Their appearance depends on the body's resistance, its relationship with microbial germs, and the virulence and the kind of invading germs.Chills and fever are usually due to toxins released by microbes, but as soon as their toxins are depleted, the clinical consequences disappear.Most of the occasional bacteria are caused by microorganisms from the indigenous microbiotic. They can be spontaneously regressive if they occur after dental extractions, other dental procedures or after surgery on normal colonized mucosa or septic outbreaks. The normal functioning of the immune defense system destroys or eliminates those bacteria, which explains the shortduration and benign, inappropriate evolution of occasional bacteremia.Numerous bacteria have been caused by dental extractions.Bacteria with an oral point of departure is concerned with Infectious Risk in Dental Practice, arguing the role and importance of dental practitioners in the prophylaxis of infections starting with the indigenous microbial flora of the oral cavity.

The pathology of the oro-maxilo-facial territory comprises a wide range of diseases with primary or secondary infectious etiology, the mouth being the natural cavity of the organism with the most varied or variable contamination flora, representing the so-called normal flora or fundamental flora [34,35].

The incidence of bacterial invasion of blood as a result of oral surgery is very much studied. The authors insist that transient bacterial infections caused by oral surgery have the potential to produce serious infectious accidents.

\section{Experimental part}

\section{Materials and methods}

The goal of dentists is to provide the patient with maximum comfort and security at the time of the intervention.The study included 243 randomly selected patients, with the address of the Oral and Maxillofacial Surgery Clinic in the period 2016-2018.

\section{Results and discussions}

The basic principles in oral surgery are asepsis and antisepsis, reduction of invasiveness, patient's intraoperative comfort, assured by analgesic, antiinflammatory and anxiolytic premedication and an efficient anesthetic technique throughout the entire intervention.

Asepsis represents the totality of physicochemical measures that have the role of preventing the operator wound from contaminating saprophytic microbial agents or pathogens; is a prophylactic method.

Antisepsis is the total of measures that have the role of destroying the germs present in a traumatic or surgical wound with the help of physicochemical agents; is a curative method. Oral Surgery and Maxillofacial includes surgical treatment of cervical and facial soft parts, visceral skull bones, salivary glands, temporomandibular joints, craniofacial deformities and malformations, reconstructive plastic in the oral and maxillo-facial spheres, and surgical treatment of dento-periodontal diseases.

In terms of pain prevention, during and after surgery, the dental clinic has the ability to provide general anesthesia or inhalation, depending on the extent of surgery and the patient's option. The surgical maneuvers performed in this group of 243 patients were dental extraction in 151 patients (62.14\%) and other surgical maneuvers in 46 patients $(18.93 \%)$, we performed the incision and drainage of the perimaxilar abscess in 31 patients (12.76\%) subgingival denture in 10 patients (4.22\%) apical resection in 5 patients (1.68\%) gingivectomy (fig.1).

The reasons for the dental extraction were manifold. Of the total of 151 dental extractions, 15 extractions 


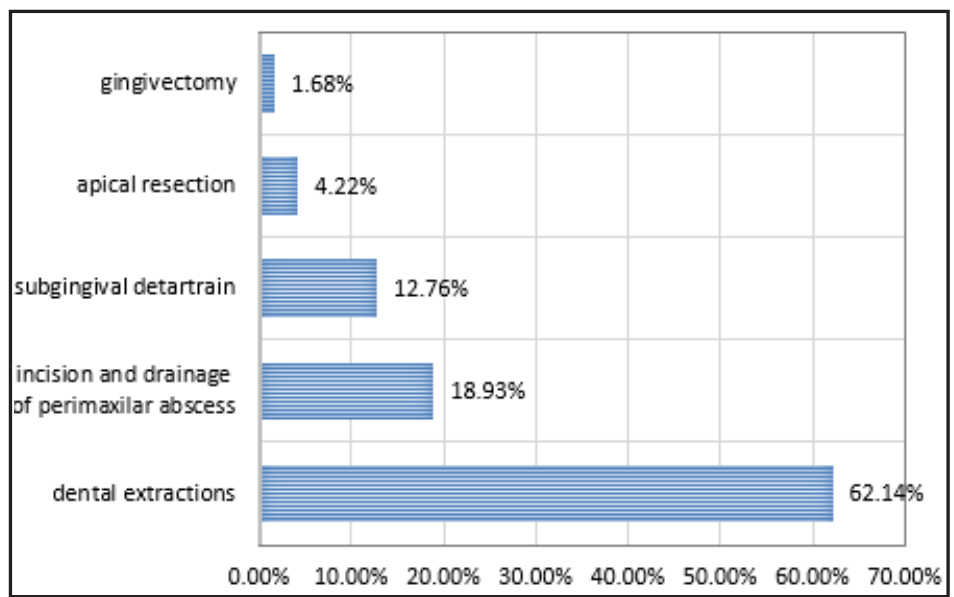

Fig.1 Distribution of surgical maneuvres performed

concerned causal teeth in a perimaxilar abscess. All these patients were at the time of extraction under the protection of antibiotics imposed by the pre-existing inflammatory disease.

Administration of antibiotics for perimaxilar abscess therapy also had an impact on post-treatment bacteremia which was found to be much lower than in the group of patients who did not have antibioprophylaxis.

The therapeutic course of oral surgery specialists at the Oral and Maxillofacial Surgery Clinic over perimaxilar abscess is: $1 \mathrm{~g}$ of amoxicillin per gram at $6 \mathrm{~h}$ for 7 days, starting one hour before perimaxilar abscess incision; incision, evacuation and drainage of the purulent collection, three days after the relief of inflammatory phenomena, the causal tooth extraction is practiced; antibiotic therapy is continued until the 7-day period is complete.

The hemocultures taken from these patients, 10 minutes after extraction, showed a percent positive of only $5.13 \%$.

This percentage of bacteria has been shown to be the lowest in the range of diagnostics that required dental extraction.

With all the evolution of surgery in general, modern antiseptics used, new generations of antibiotics, the problem is that a consequence of bacteremia after dental care procedures, post-treatment especially remains a present feared presence; the best method of prophylaxis is a judicious antibiotic prophylactic antibiotherapy.Many of the prophylactic methods are within reach of the practitioner, provided they are respected and applied as follows: dental-periodontal trauma during dental care is advised to be mitigated; soft tissue and bone lesions are reduced, controlled hemorrhage; safe, precise dental extraction technique without large and unnecessary pendulums in the dental dislocation movement; the use of anestesic solutions with vasoconstrictor whenever the general condition allows it.

It is recommends a broad action to improve the oral health of the population through regular professional care, the use of optimal and quality dental products, conscious, normal and rotativ brushing of teeth, dental floss and other methods of removing the bacterial plaque, all for prophylactic purposes, reduction of bacteremia after dental procedures, prophylaxis with oral intake.If dental extraction seems to be a simple and rapid maneuver for most dental practitioners, well-documented dental surgeons are a complex surgical procedure that involves local and general risks and requires an important set of precautions and practical knowledge.

Risk antibiotic prophylaxis is recommended in dental and oral procedures that can cause bacteremia, generally procedures associated with major bleeding from hard or soft tissues, parodontal surgery, root surfacing, forceful, vigorous, traumatic brushing.The special etiological spectrum of oral germs, which through the act of dental extraction can be introduced into the circulatory torrent by the capillaries that break at the operative moment, requires special attention to the bacteremia that can occur after the dental extraction. It is important for the dental practitioner or oral surgeon to know first the conditions that favor and support the emergence of a bacterium condition after the extraction of a tooth or more.

\section{Gingivectomy Remodeling}

is a safety procedure and with predictible results which is designed to remove excess tissues of gum to improve the appearance of a smile reach the present times. The first step in gingivectomy or gingival remodeling is to make sure all the areas involved are perfectly anesthetized. After it makes a small incision and remove the gum tissue in excess. Gingivoplasty is the procedure by which we remodel and surgically reconstitute gingival tissue for cosmetic, physiological or functional purposes. Gingivoplasty is the surgical reshaping of the outer surfaces is gum and it is practiced usually in combination with gingivectomy. Many patients have a gingival smile that can be caused by excessive gingival tissue. This increased excess tissue can in most cases be removed for the blushing smile she hides. After practicing gingivectomy, gingivoplasty reduces the remaining gingival tissue so that after the healing the gums have a natural and pleasant look.

\section{Conclusions}

The most common bacterial disease is the dental extraction.

A dentist must gather at the critical time all possible means to prevent a bacteremia, or if it is already, to avoid it.

As a first step towards meeting this goal, the dentist must strictly and meticulously observe the general surgical rules of asepsis, antisepsis and hygiene to reduce the number of bacteria that are open to the bloodstream through oral mucosal solutions

\section{References}

1.***French Health Products Safety Agency (Afssaps).Prescribing antibiotics in odontology and stomatology. Recommendations by the French Health Products Safety Agency. Fundam Clin Pharmacol 2003; 17:725-729. 
2.HARASZTHY VI, ZAMBON JJ, TREVISAN M, ZEID M, GENCO RJ. Identifica-tion of periodontal pathogens in atheromatous plaques. J Periodontol 2000; 71(10): 1554-1560.

3.OKELL CC, ELLIOTT D. Bacteremia and oral sepsis with special reference to aetiology of bacterial endocarditis. Lancet 1935;2:869872.

4.RAJ ASUO A, PERKKI K, NYFORS S, J OUSIMIES-SOMER H, MEURMAN $\mathrm{JH}$. Bacteremia following surgical dental extraction with an emphasis on anaerobic strains. J Dent Res 2004;83:170-174 Lockhart PB, Brennan MT, Kent ML, Norton HJ , Weinrib DA. Im-pact of amoxicillin prophylaxis on the incidence, nature, and duration of bacteremia in children after intubation and dental procedures. Circulation 2004;109:28782884.

5.TSUNODA R, SUDA S, FUKAYA T, SAITO K. Descending Necrotizing Mediatinitis Caused by an Odontogenic Infection: a Case Report. J Oral Maxillofac Surg 2000; 58: 240-2.

6.ARMSTRONG JE, DARLING MR, BOHAY RN, COBB G, LAWEN D, DALEY TD: Trans-geniohyoid dermoid cyst: considerations on a combined oral and dermal surgical approach and on histogenesis. J Oral Maxillofac Surg 64(12):1825-30, 2006.

7.CHINN L: Exophytic growths on the gingiva. Squamous papillomas. Gen Dent 55(4):367, 371, 2007.

8.McGUFF HS, ALDERSON GL, JONES AC: Focal fibrous hyperplasia (irritation fibroma). Tex Dent J 123(4):388-9, 392, 2006.

9.YUEN HW, JULIAN CY, SAMUEL CL: Nasolabial cysts: clinical features, diagnosis, and treatment. Br J Oral Maxillofac Surg 45(4):293-7, 2007. 10.PERDIGAO PF, SILVA EC, SAKURAI E, SOARES DE ARAUJ O N, GOMEZ RS: Idiopathic bone cavity: a clinical, radiographic, and histological study. Br J Oral Maxillofac Surg 41(6):407-9, 2003.

11.LOPEZ-ARCAS CALLEJ A JM, CEBRIAN CARRETERO JL, GONZALEZ MARTIN J, BURGUENO M: Aneurysmal bone cyst of the mandible: case presentation and review of the literature. Med Oral Patol Oral Cir Bucal 12(5):E401-3, 2007.

12. NICULESCU,O.,NICA,P., GURLUI,S.,et al., Experimental investigations of polymer plasma laser ablation, Mat.Plast., 46, no.3, 2009, pg.336-338

13. VASLUIANU, E., POPESCU,V., GRIGORIU,A., et al., Comparative study concening the FIR Analysis and the performances of chitosan based w rinkle-proofing agents, Rev.Chim.(Bucharest), 64, no.10, 2013, pg.1104-1115

14. NASH,D.,RUOTOISTENMAKI, ., ARGENTIERI,A.et al.,Profil of the oral healhcare team in countries with emerging economies, Conference Global Congress on Dental Education location,Dublin,Ireland, European J ournal of Dental Education,12((1), 2008, pg.111-119

15. POPESCU,V., VASLUIANU,E., FORNA,N.C., et al., Comparative study of the FTIR Analysis and the peformances of N,N,N-trimethyl chitosan as wrinke-poofing agent, Revista Rev.Chim.(Bucharest) , 64, no.11,2013, pg.1284-1294

16. BOTNARIU,G., FORNA, N., POPA,A., et al., Correlation of glycemic control parameers in non-diabetic pesons with cardiovascular risk scores-results from a cross-sectional study, 8(1),2017, pg.108-110

17. IFTENI,G., APOSTU,A., TANCULESCU,O., Dental occlusion and the importance of is proper investigation-partll, Romanian Journal of Oral Rehabilitation, 8(4),2016,pg.17-22

18. JUMANCA ,D., GALUSCAN,A., PODARIU, A.C., et al.,Antiinflammatory action of toothpastes conaining betulin nanocapsules, Rev.Chim.(Bucharest), 65, no.12, 2014, p.1473-1476

19. BALAN G., GRIGORE, C.A., BUDACU,C.C., et al., Antisepsis, Desinfection Sterilization -mehods used in dentistry, Rev.Chim.(Bucharest), 68, no.1, 2017, pg.186-191

20. ZEGAN, G., DASCALU, C.G., MAVRU, R.B., Cephalometric, features of Class III malocclusion, Medical-surgical journal,119(4), ,2015, 11531160;
21.ANCUTA ,C., POMIRLEANU, C., IORDACHE,C., et al., Serum lipid profile in diffuse versus limited systemic sclerosis data from the SASS cohort, Rev.Chim.(Bucharest), 69, no.2,2018, p.403-406

22. BUDACU, C.C., CIORANU,S.V.,CHISCOP,I.,E al., Glucocoricoids and postoperative disease in oral-maxillofacial surgery,

Rev.Chim.(Bucharest),68, no.11,2017,p.2716-2719

23.NEMTOI, A., DANILA ,V., DRAGAN, E., et al., The effecs of insulin and strontium ranelate on guided bone regeration in diabetic rats, Rev.Chim.(Bucharest),68, no.4, 2017,pg.693-697

24.ANCUTA,C., POMARLEANU,C., IORDACHE C., Periodontal disease and lipid profile in systemic sclerosis: an EUSTAR Cohot Expeience, Rev.Chim.(Bucharest),68, no.4, 2017,pg.890-893

25. IORDACHE,C.,GHIORGE,C.A., ANTOHE M.E., et al., Temporomandibular joint involvement in rheumatoid arthritis and ankylosing spondylitis:a cross-sectional study, 994),2017, pg.40-46

26. MURARIU,A., PRICOP M., BOBU,L., e al., Ethics dimensions in dentistry, Romanian J ournal of Oral Rehabiliation,8(1), 2016,pg.65-71

27.POPA , C., STELEA C.G., FILIOREANU,A.M., et al., PCR Analysis of the Herpesviruses presence in crevicular fluid in HIV-positive patients, Rev.Chim.(Bucharest),68, no.11, 2017, 2672-2675.

28.DUCEAC, LD, STAFIE, L, VALEANU, IP, MITREA, G, BACIU, G, BANU, EA, ROMILA, L, LUCA, AC. Sepsis in paediatrics - a special form of infection associated to medical assistance. INTERNATIONAL JOURNAL OF MEDICAL DENTISTRY, 2018, 22(3): 229-235.

29.BOTNARIU, G, POPA, A, MITREA, G, MANOLE, M, PACURA, M, ANGHELE, M, CURIS, C, TEODORESCU, E. Correlation of Glycemic and Lipid Control Parameters with Cognitive Dysfunction Scores, in Type 2 Diabetic Persons Results from a cross- sectional study. Rev.Chim.(Bucharest), 69, no.12, 2018, p.3486-3489.

30.FORNA AGOP ,D., POPESCU, E., COSTAN V.V., et al.,Conventional maxillary reconstruction using service obturators, Romanian Journal of Oral rehabilitation,(8),3,2016, pg.32-39

31.COSTACHE ,I.I., COSTEA .C.F, DANCIU,M., COSTAN, V.V., AURSULESEI,V., DUMITRESCU,G.F., TURLIUC, M.D,SAVA ,A., Amyloidosis-a rare cause of refractory heart failure in a young female, Rom J Morphol Embryol, 2017,58(1),201-2016

32.DASCALU, C.G., CARAUSU, E.M., MANUC, D., Methods for Data Selection in Medical Databases: The Binary Logistic Regression Relations with the Calculated Risks, Proceedings of world academy of science, engineering and technology, VOL 28 Book

Series: Proceedings of World Academy of Science Engineering and Technology Volume: 28 Pages: 278-+ Published: 2008

33.BRANISTEANU,D.E.,IANOSI,S.L.,DIMITRIU,A., et al., Drug-induced Rowell syndrome, a rare and dufficult to manage disease:A case report, Experimental and therapeutic medicine,15(1), 2018,p. 785. 34.BOTEZATU, C, DUCEAC, LD, MASTALIER, B, STAFIE, L, JITAREANU, CM, LUCA, AC, TARCA, E, MITREA, G, IORDACHE, AC, PATRASCU, T. Hepatic cystic echinococcosis studied in a family group. INTERNATIONAL JOURNAL OF MEDICAL DENTISTRY, 2018, 22 (4): 346-350.

35.DUCEAC, LD, LUCA, AC, MITREA, G, BANU, EA, CIUHODARU, MI, CIOMAGA, I, ICHIM, DL, BACIU, G. Ceftriaxone Intercalated Nanostructures Used to Improve Medical Treatment. Mat.Plast, 55, no.4, 2018, p. 613-615

36.EARAR, K., ANTONIAC, V.I., BACIU, S., et al, Etching treatment effect on surface morphology of dental structures, Rev.Chim. (Bucharest),68, no.11,2017, p.2700

37.SCUTARIU,M.M., CIURCANU,O.E., FORNA AGOP, D. Et al. , Importance of dental maxillofacial aesthetic in dental therapy, Medicalsurgical journal, revista medico-chirurgicala, 120(4), 2016, p.926

$\overline{\text { Manuscript received: } 17.12 .2018}$ 